\title{
Differential response of communities of plants, snails, ants and spiders to long-term mowing in a small-scale experiment
}

\author{
P. Pech ${ }^{1,5}$, J. Dolanský ${ }^{2}$, R. Hrdlička ${ }^{3}$ and J. Lepš̌ $\check{3}^{3,4}$ \\ ${ }^{1}$ Faculty of Science, University of Hradec Králové, Rokitanského 62, Hradec Králové 500 03, Czech Republic \\ ${ }^{2}$ The East Bohemian Museum in Pardubice, Zámek č.p. 2, Pardubice 530 02, Czech Republic \\ ${ }^{3}$ Faculty of Science, University of South Bohemia, Branišovská 31, České Budějovice 370 05, Czech Republic \\ ${ }^{4}$ Institute of Entomology, Academy of Sciences of the Czech Republic, Branišovská 31, České Budějovice 37005 , \\ Czech Republic \\ ${ }^{5}$ Corresponding author. E-mail: pavelpech1@centrum.cz; Phone: +42493331191
}

Keywords: Araneae, Biodiversity, Formicidae, Management, Mollusca, Plants.

\begin{abstract}
We examined the response of communities of four groups of organisms (plants, snails, ants and spiders) in a small scale mosaic of 8-years mown and unmown plots in a wet meadow in Central Europe. The experimental setup consisted of 7 unmown and 8 regularly mown $4 \mathrm{~m}^{2}$ plots in checkerboard arrangement. Eight years after the start of the experiment, the plant community structure diverged in response to mowing/nonmowing, both in species composition and structure. Both bryophyte and vascular plant species numbers were significantly higher in the mown plots. In unmown plots, bryophytes nearly disappeared and plots were dominated by the tall tussock grass Molinia caerulea. Both diversity and abundance of snails were higher in unmown plots than in mown ones. Ant nests were more abundant in mown plots and species composition differed between mown and unmown plots. We captured significantly more individuals of spiders in mown plots but we did not find any difference in species composition. We conclude that the 8-years duration of different management of $4 \mathrm{~m}^{2}$ plots was sufficient to establish different communities in low movable organisms, whereas these plots are probably too small to host different assemblages of organisms with good active dispersal abilities.
\end{abstract}

Abbreviations: RDA-Redundancy Analysis; PCA-Principal component analysis.

Nomenclature: Ants - Seifert (2007); bryophytes - Kučera et al. (2012); molluscs - Horsák et al. (2013); spiders - Platnick (2013); vascular plants - Kubát et al. (2002).

\section{Introduction}

The majority of grasslands in Central Europe are seminatural, human-made habitats, kept open by mowing and grazing regimes, both historically and recently. It is well documented that biodiversity, and community structure and composition of a given grassland area is largely influenced by the management regime (for recent examples see Doležal et al. 2011, Grandchamp et al. 2005, Humbert et al. 2010, Hyvonen and Huusela-Veistola 2011, Marini et al. 2009, Steffan-Dewenter and Leschke 2003, Weiner et al. 2011).

In general, the diversity of higher plants in mown plots is higher than in abandoned plots (Fenner and Palmer 1998, Gerard et al. 2008, Huusela-Veistola and Vasarainen 2000, Lepš 1999), although it decreases if mowing is too frequent (e.g., Zechmeister et al. 2003). Mowing prevents succession, reduces competitiveness and offers opportunities for weak competitors (Scanga and Leopold 2012).

In case of invertebrates, the situation is more complicated. Many individuals can be killed directly during mowing and mowing reduces an amount of shelters for overwintering and an amount of food supply (Humbert et al. 2009, 2010,
Konvicka et al. 2008, Fenner and Palmer 1998, Dover et al. 2010). Thus, the management can lead to the lower biodiversity of some invertebrate taxa on mown plots than in unmown (Fenner and Palmer 1998, Steffan-Dewenter and Leschke 2003).

On the other hand, there are a couple of studies that do not support these results. The abundance and diversity of some arthropods (ants, spiders, carabids and curculionids) on road verges increased with the frequency of mowing (Noordijk et al. 2010). The amount and diversity of ground beetles (Carabidae) was positively correlated with the intensity of management (mowing, grazing, fertilizing) in Gradchamp et al. (2005) study. Mown plots exhibited a higher diversity of Orthoptera compared to the abandoned plots (Marini et al. 2009). Not only the type of management but also its timing play an important role, as demonstrated by Humbert et al. (2012). Moreover, many grassland organisms (many of them endangered) are restricted to short swards and disappear with succession (e.g., Dekoninck et al. 2007, Huusela-Veistola and Vasarainen 2000).

Some studies suggested that the mosaic of mown and unmown plots shows the highest diversity of both plants and 
invertebrates (Balmer and Erhardt 2000, Cizek et al. 2012, Gathmann et al. 1994, Kuussaari et al. 2011, Valkó et al. 2012). Whereas the effect of mowing varies among taxonomical groups (some groups are enhanced whereas others suppressed), the general community of organisms in the mosaic is expected to contain species from both ecological groups. Moreover, some species benefit from the possibility of easily moving between both habitats (e.g., feed in one and breed in the other).

Most of the studies cited above deal with large plots that enabled to obtain a huge amount of data. On the other hand, the differences of the biodiversity between small mown and unmown plots remain little known.

We have experimentally created a small scale mosaic of mown and unmown plots in a seminatural oligotrophic meadow, and studied the effect of 8-year management on four groups of organisms: plants (which, following phytosociological tradition included vascular plants and bryophytes), snails (Mollusca: Gastropoda), ants (Formicidae) and spiders (Araneae). All selected taxonomic groups are often used as indicators of natural value (e.g., Báldi et al. 2013, Brandao et al. 2011, Cremene et al. 2005, Diamond et al. 2012, Ellison 2012, Peck et al. 1998, Schwab et al. 2002, Scohier and Dumont 2012). Our main questions were: How the assemblages of selected organisms respond to the mowing in the small scale with respect to the structure, abundance and species composition? Are the differences less pronounced in organisms with good dispersal and vagility?

\section{Methods}

\subsection{Study site and data collection}

The experiment was established in an oligotrophic wet species-rich meadow $10 \mathrm{~km}$ southeast from České Budějovice, Czech Republic ( $48^{\circ} 57^{\circ} \mathrm{N}, 14^{\circ} 36^{\circ} \mathrm{E}, 510 \mathrm{~m}$ a.s.1.). Mean annual temperature is $7.8^{\circ} \mathrm{C}$, and mean annual precipitation is $680 \mathrm{~mm}$ (České Budějovice Meteorological station, $9 \mathrm{~km}$ from the plots). The meadow (ca 1 hectare) is surrounded on three sides by forest and one side borders a field. The meadow surrounding the experiment is mown once or twice a year (late June or early July and usually also September/ October) at height $3-5 \mathrm{~cm}$.

The experimental plots were established in a homogenous part of the wet meadow dominated by Molinia caerulea, other common grasses were Nardus stricta, Festuca rubra, and Holcus lanatus. The meadow was species rich, hosting over ten species of sedges (e.g., Carex panicea, C. hartmanii, C. nigra, C. pallescens, C. pilulifera) and many forb species. According to phytosociological classification, it can be characterized as Molinion caeruleae Koch 1926 with some species of the Violion caninae Schwickerath 1944.

In total, 15 experimental plots (each plot $2 \mathrm{~m} \times 2 \mathrm{~m}$ ) in checkerboard arrangement (five rows and three columns) were established in mown meadow in 2002. Eight plots were mowed once or twice a year by brush cutter with litter removal (the same management as on the rest of meadow), seven were left without mowing. The area was regularly mown before the start of the experiment. The experiment was established in a meadow with various ongoing long-term manipulative experiments (e.g., Lepš 1999, Vítová and Lepš 2011); the original aim of this experimental design was to get sufficient plots for traits and ecophysiological measurements of plant individuals. The plant species composition was not regularly monitored, but the area was visually homogeneous at the time of establishment, and during the years, it developed into a checkerboard of well differentiated communities. Species composition was not recorded in the plots before the experiment started in any group, but there was homogeneous vegetation and so there is no reason to expect differences in these groups of invertebrates. In particular, the checkerboard design of the experiment practically precludes any systematic differences at the start of the experiment, and so, all the differences can be unequivocally considered to be a consequence of different management.

Plants. The species composition of plants (both bryophytes and vascular plants) was recorded in June 2011 and the cover of individual species was visually estimated in each of the plots, similarly as cover of litter at the time of sampling.

Molluscs. A $30 \mathrm{~cm} \times 30 \mathrm{~cm}$ sample of leaf litter and top soil was taken from the centre of each plot in August 2010 to find molluscs. The material was dried out, screened using several sieves and searched carefully for empty shells and living molluscs. Molluscs were determined in the laboratory. Shells and living individuals were not distinguished.

Ants. It was searched for ant nests using a garden rake in all plots on 11.8.2010. The position of each nest in external (up to $10 \mathrm{~cm}$ from the habitat border) or internal area of each plot was recorded. A sample of ants (5-10 workers) from each nest was taken, preserved in $96 \%$ alcohol and determined in the laboratory.

Spiders. Spiders were collected using pitfall traps. One trap filled by water with detergent was exposed in the centre of each experimental plot for 3-4 days at approximately two weeks intervals from June to September in 2011 and from May to September in 2012. Captured spiders were preserved in $96 \%$ ethanol and determined in the laboratory. Stereomicroscope was used when it was needed for the identification.

Soil acidity was measured in 2011 due to possible impact on snails. $80 \mathrm{~g}$ of dry soil from each plot diluted in 200 $\mathrm{ml}$ of distilled water was measured using inoLAB $\mathrm{ph} / \mathrm{ION}$ Level 2. It can be expected, and we have demonstrated this in concurrently running experiment at the same locality, that the soil surface temperature is higher on sunny days in the mown plots (Lepš 1999).

\subsection{Statistical analysis}

Amount of litter, soil acidity and the numbers of species or colonies were compared between mown and unmown plots by two-sample t-test. The species composition was compared using Redundancy Analysis (RDA) with mowing as the only explanatory variable using the Canoco 5 package (ter Braak and Šmilauer 2012). No standardization by species 
was applied. Two analyses were always performed, one with standardization by sample norm and one without. When the standardization by sample norm was applied, only the relative proportions of species were compared. With no standardization by sample, the differences might be caused either by differing total numbers (e.g., of colonies), or by different proportions of individual species (Šmilauer and Lepš 2014). Each ordination is characterized by explained variability by the model (as we have only one binary explanatory variable, it is the explained variability by the first axis). Because this value is affected by the size of the matrix, we used also the efficiency of the first axis, i.e., the ratio of the explained variability by a constrained axis to the explained variability of the corresponding unconstrained axis - in our case it is the ratio of explained variability by the first axis of RDA to the explained variability by the first axis of corresponding PCA (Šmilauer and Lepš 2014).

Because the species richness is dependent on the number of individuals, we also compared the rarefaction curves for molusc and spider individuals and for ant nests. We used pooled set of individuals (nests) from all the plots of each category. The equation of Hurlbert (1971) and the program Analytic Rarefaction 1.3 (http://strata.uga.edu/software/anRareReadme.html) was used.

\section{Results}

Plants

The number of both bryophyte and vascular plant species was significantly higher in the mown plots (bryophytes: $\mathrm{t}=9.61$, d.f. $=13, \mathrm{P}<0.01$; vascular plants: $\mathrm{t}=6.28$, d.f. $=13$, $\mathrm{P}<0.01$ ) (Fig. 1a,b). The species composition was also significantly different, both with and without standardization by sample norm (Fig. 2, Table 1). High efficiency of the constrained axis proves that mowing is really the determinant of plant species composition. In unmown plots, the bryophytes nearly disappeared, whereas the mown plots usually hosted several species (e.g., Rhytidiadelphus squarrosus,

a

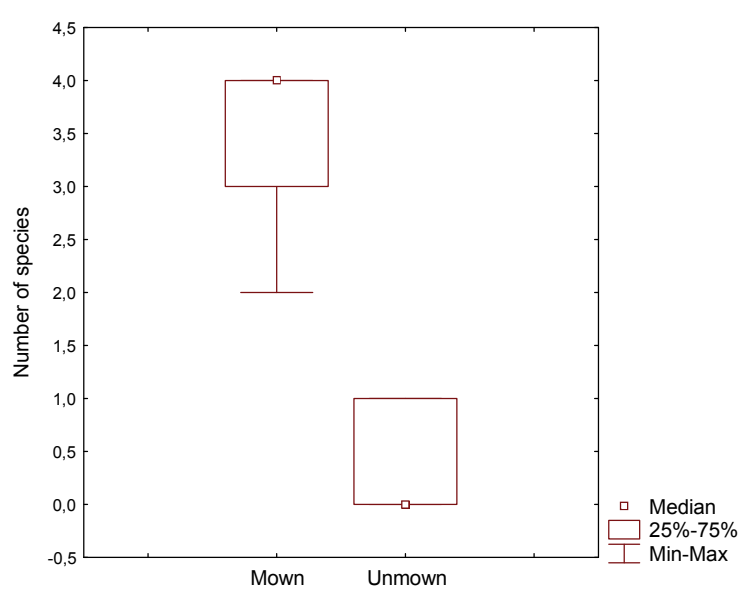

Pseudoscleropodium purum). In addition, most vascular species preferred mown plots, and shorter plants in particular almost disappeared from unmown plots (e.g., Valeriana dioica, Anthoxanthum odoratum, Luzula multiflora). The unmown plots were highly dominated by the tall tussock grass Molinia caerulea, and the relatively tall species, Lysimachia vulgaris also showed a preference for the unmown plots (Appendix 1). This contributed to the significantly taller vegetation of unmown plots; the dominant species Molinia caerulea reaching heights of over $1 \mathrm{~m}$ at the end of the season, compared to most plants in mown plots that were usually $<0.5 \mathrm{~m}$. Molinia caerulea was also common in mown plots (this is why it is not among the species well fitted by the first axis of RDA, Fig. 2), nevertheless, due to mowing it was considerably shorted at the end of the season, and so its competitive effect was not so strong; it also did not form compact tussocks there. There was also much more litter in unmown plots (estimated cover $56 \%$ vs. $7 \%$ in mown plots, $\mathrm{t}=21.7$, d.f. $=13, \mathrm{P}<0.01$ ), consisting mostly of slowly decomposing litter of Molinia caerulea.

\section{Molluscs}

In total, 419 molluscan individuals of 11 species were found: 141 individuals in mown and 278 individuals in unmown plots. Four species were found exclusively in unmown plots (Columella aspera, Vertigo pygmaea (Draparnaud), Vitrina pellucida and Galba truncatula); the rest (seven species) were present on plots of both types. Both diversity and abundance of snails were significantly higher in unmown plots than in mown (number of species: $\mathrm{t}=-4.29$, d.f. $=13, \mathrm{P}<0.01$; abundance: $\mathrm{t}=-3.83$, d.f. $=13, \mathrm{P}<0.01$ ) (Fig. 3a,b; Appendix 1). Rarefaction of the pooled set of individuals from all plots of each treatment demonstrated that the higher number of species in unmown plots is not only consequence of higher number of individuals sampled there (Appendix 2a). Species composition was significantly different without standardization by sample norm (Fig. 4) but not with this standardization (Table 1). The differences cannot be caused by $\mathrm{pH}$, because there was no significant difference in soil $\mathrm{pH}$ between experimental plots $(\mathrm{t}=0.66$, d.f. $=13, \mathrm{P}>0,05)$.

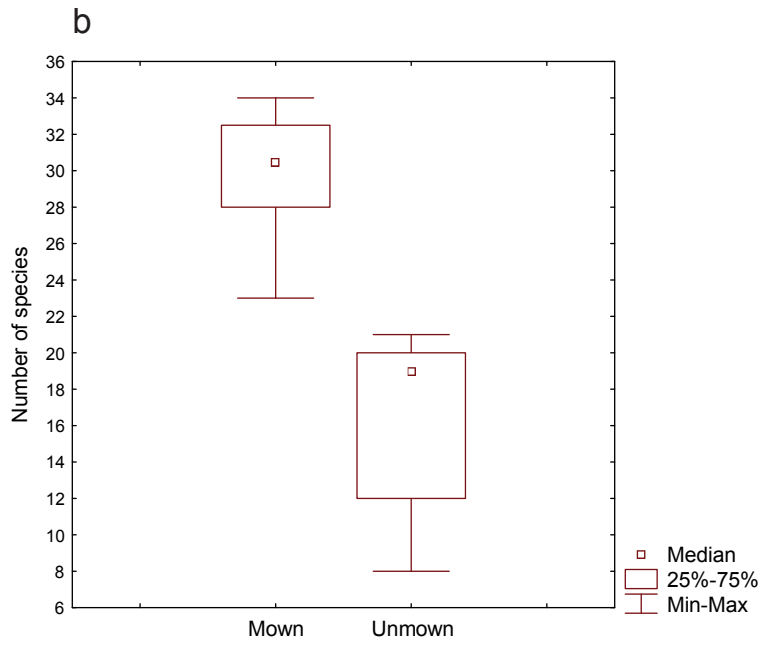

Figure 1. Species richness of bryophytes (a) and vascular plants (b) in mown and unmown $2 \mathrm{~m} \times 2 \mathrm{~m}$ plots. 
Table 1. The basic characteristics of the RDA ordination results of individual groups of organisms. Standardization - standardization by sample norm. Explained \% - proportion of total variability explained by the mowing (i.e., by the first RDA axis). Efficiency - ratio of the variability explained by first RDA axis to the variability explained by the first axis of corresponding PCA. F - the pseudo-F value. $\mathrm{P}$ - probability obtained by the Monte Carlo permutation test.

\begin{tabular}{lccccc}
\multicolumn{1}{c}{ Organisms } & Standardization & Explained $\%$ & Efficiency $\%$ & F & P \\
Plants & No & 46.72 & 93.27 & 11.4 & 0.0004 \\
Plants & Yes & 48.33 & 93.31 & 12.2 & 0.0004 \\
Moluscs & No & 23.08 & 44.36 & 3.9 & 0.0148 \\
Moluscs & Yes & 14.49 & 25.79 & 2.2 & 0.1000 \\
Ants & No & 48.62 & 51.80 & 12.3 & 0.0032 \\
Ants & Yes & 22.50 & 37.74 & 3.8 & 0.0096 \\
Spiders & No & 10.15 & 30.34 & 1.5 & 0.1412 \\
Spiders & Yes & 9.86 & 37.11 & 1.4 & 0.1316
\end{tabular}

Figure 2. Results of RDA of plant species composition centering by species, no standardization by samples. Only 15 species best fitting the first (i.e., the only constrained axis) are displayed for clarity. Bryophyte species are underlined. Numbers signify the percentage of variance explained by individual axes. Note that only the first axis is constrained, i.e., only the first axis corresponds to the difference between mown and unmown plots.

a

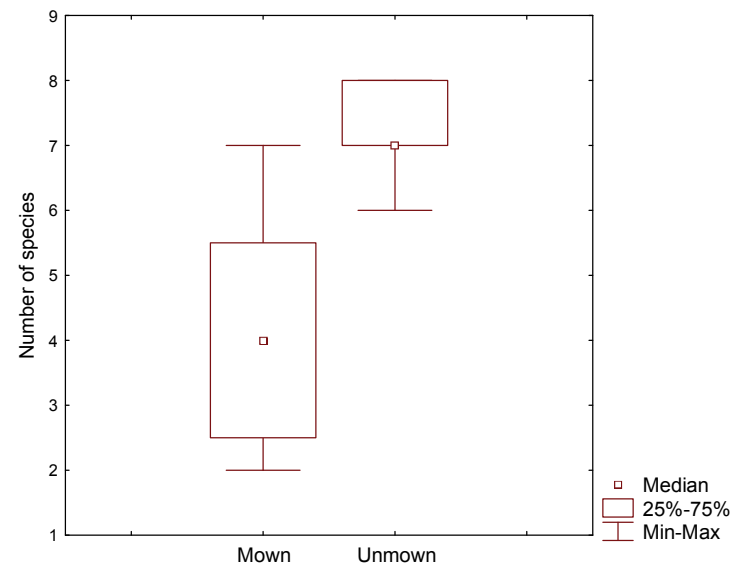

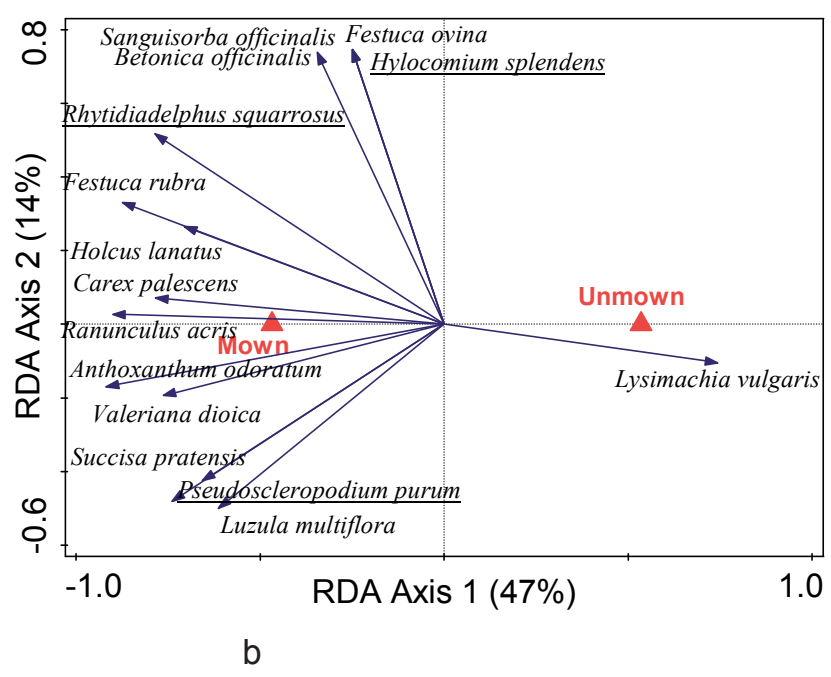

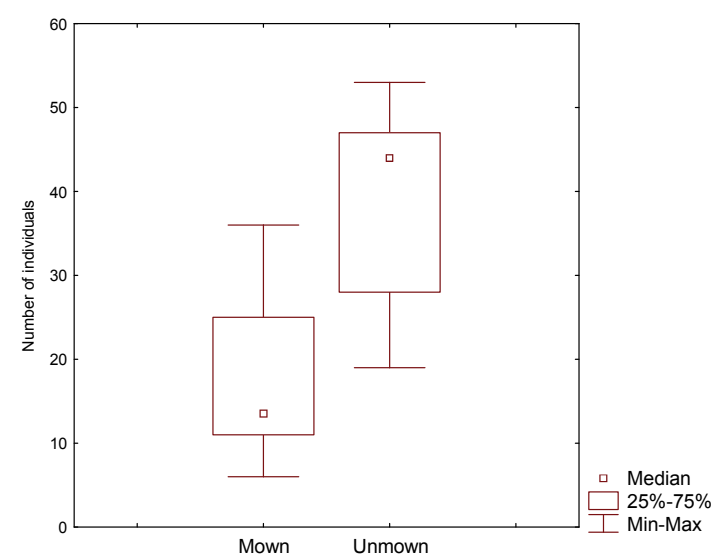

Figure 3. Species richness (a) and abundance (b) of molluscs in mown and unmown $2 \mathrm{~m} \times 2 \mathrm{~m}$ plots.

Ants

Seven ant species and 89 nests occurred in mown plots, whereas only four species and 31 nests occurred in unmown plots (Formica picea, Formica sanguinea and Myrmica vandeli were absent from unmown plots). The difference in numbers of ant species between both management types was not significant $(\mathrm{t}=-0.14$, d.f. $=13, \mathrm{P}>0.05$ ) (Fig. 5a). Mown plots hosted significantly more nests than unmown plots $\mathrm{t}=3.75$, d.f. $=13, \mathrm{P}<0.01$ ) (Fig. 5b) (Appendix 1). Differences in species composition were significant (both standardized and nonstandardized, Fig. 6), but the differences are caused mainly by proportions of dominants. Myrmica scabrinodis was the dominant species in mown plots whereas M. ruginodis domi- 


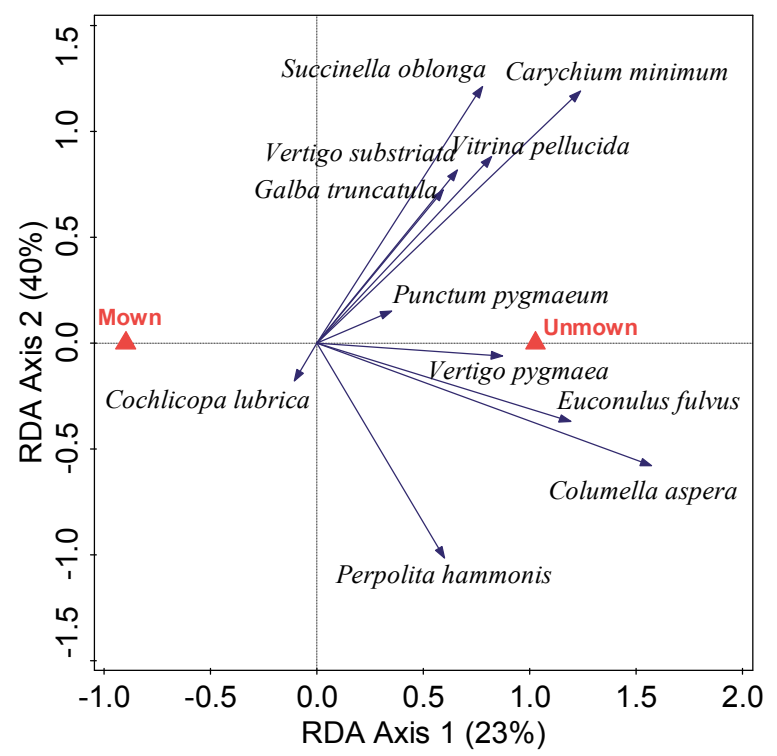

Figure 4. Results of RDA of molluscan species composition; centering by species, no standardization by samples. Numbers signify the percentage of variability explained by individual axes. Note that only the first axis is constrained, i.e., only the first axis corresponds to the difference between mown and unmown plots.

a
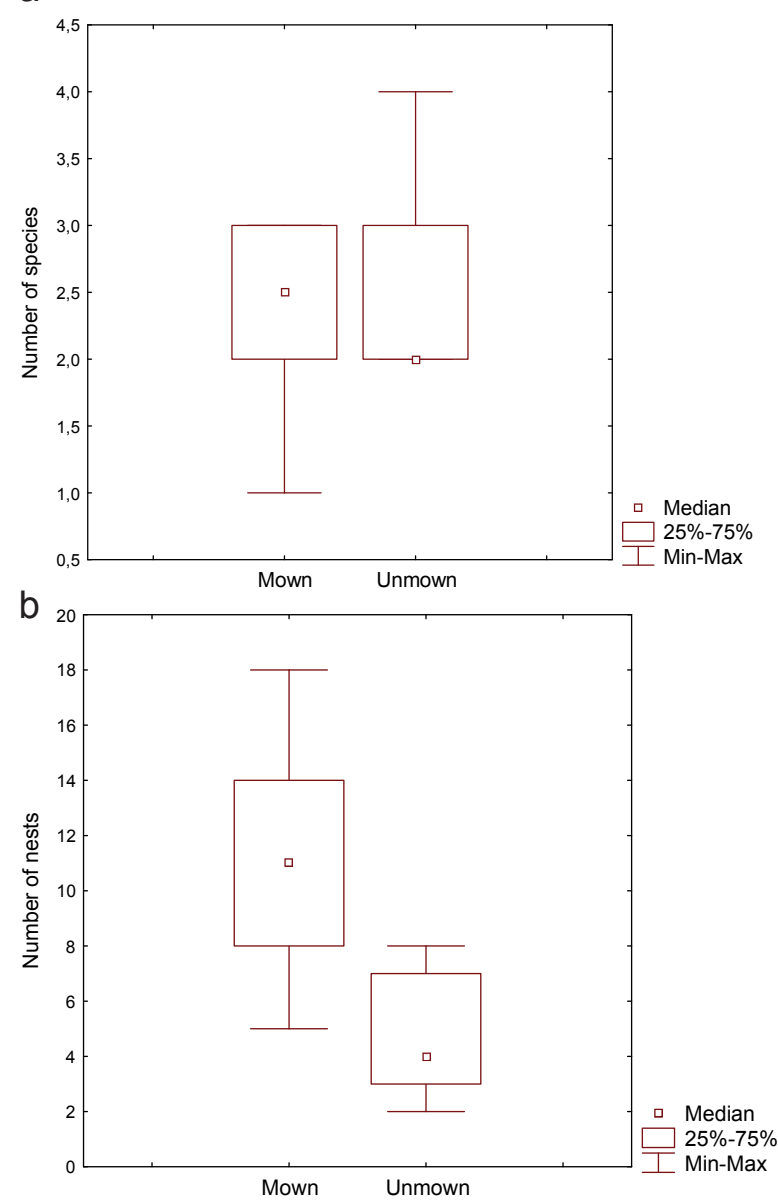

Figure 5. Species richness (a) and numbers of nests (b) of ants in mown and unmown $2 \mathrm{~m} \times 2 \mathrm{~m}$ plots.

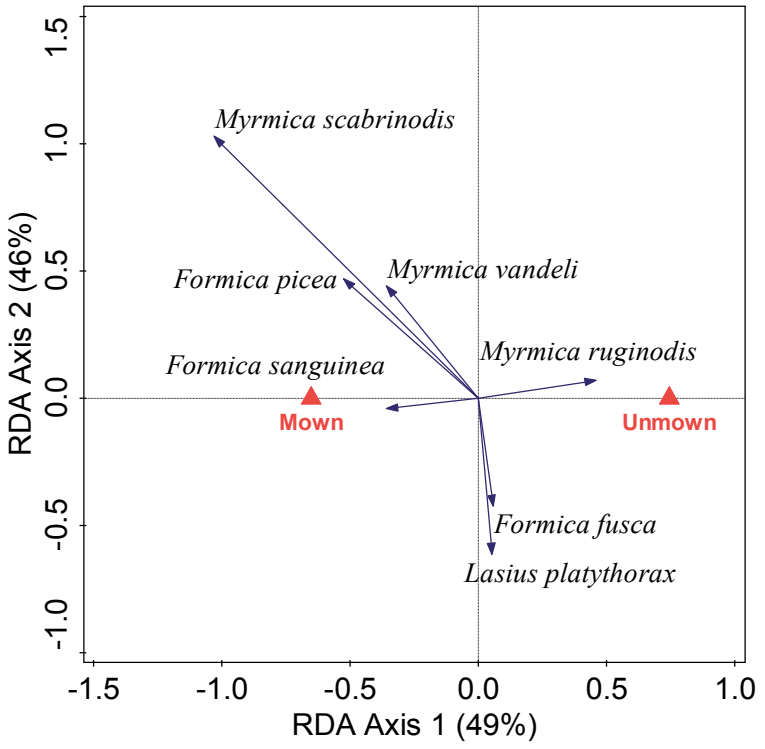

Figure 6. Results of RDA of ant species composition; centering by species, no standardization by samples. Numbers signify the percentage of variability explained by individual axes. Note that only the first axis is constrained, i.e., only the first axis corresponds to the difference between mown and unmown plots.
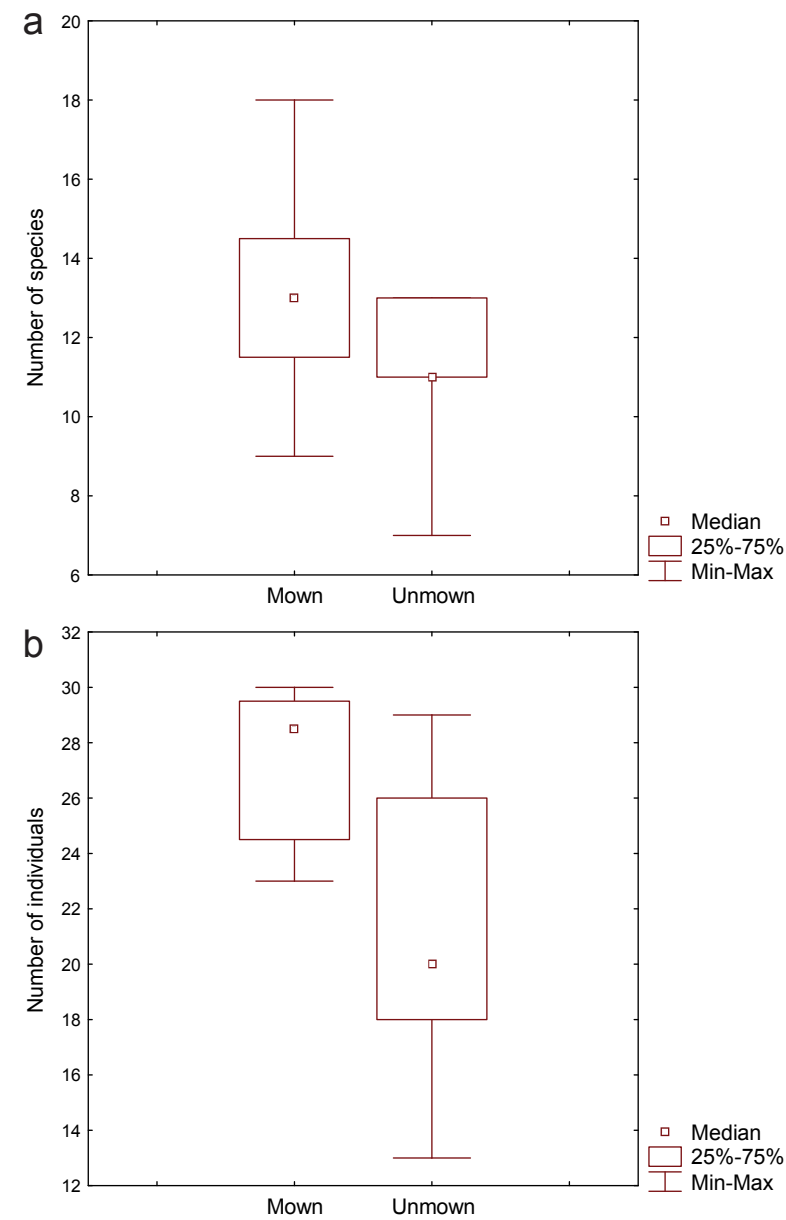

Figure 7. Species richness (a) and abundance (b) of spiders in mown and unmown $2 \mathrm{~m} \times 2 \mathrm{~m}$ plots. 
nated in unmown plots. In unmown plots, M. scabrinodis nests concentrated in peripheral areas (where nest densities were 2 nests $/ \mathrm{m}^{2}$ compared to 0,3 nest $/ \mathrm{m}^{2}$ in internal areas on average). We found no such relationships between nest densities in peripheral and internal areas in mown plots (2.1 nests/ $\mathrm{m}^{2}$, and 2.4 nests $/ \mathrm{m}^{2}$ respectively).

\section{Spiders}

In total, 604 spider individuals were captured. From this, 364 individuals belonging to 49 species were identified to species level: 41 species and 218 individuals were captured in mown plots whereas 36 species and 146 individuals were in traps in unmown plots (Appendix 1). There was no difference between number of species ( $\mathrm{t}=1.58$, d.f. $=13, \mathrm{P}>0.05$ ) (Fig. $7 \mathrm{a})$ but there were significantly more individuals in mown plots $(\mathrm{t}=2.92$, d.f. $=13, \mathrm{P}<0.05)$ (Fig. $7 \mathrm{~b})$. Concordantly, the rarefaction suggests that after initial increase, the number of species does not increase too much with further increasing number of individuals. No difference in species composition was found both with and without standardization by sample norm.

\section{Discussion}

The effect of mowing was most pronounced in plants, and less pronounced in spiders, where only the total number of individuals changed, but neither species composition, nor species richness. The intermediate effect was found in molluscs (where both the number of individuals and species was higher in unmown plots), and ants (where the differences were mainly in relative representation of dominants) (Table 1).

Eight years after the start of the experiment, the plant community structure has diverged according to mowing/nonmowing treatments. This result corresponds with many vegetation studies (e.g., Lepš 1999, at the same locality). Because another long term experiment has been running concurrently at the locality since 1994 (Lepš 1999, 2004, 2014), containing plots under the same management, we can expect that in the present experiment, the most pronounced divergence already happened. The mowing results in changes of temperature (Lepš 1999) and moisture, which are directly important for the survival of many animals. Unmown plots were more heterogeneous, consisting of turfs of grasses and wet depressions among them and offering more microhabitats than rather homogenous mown plots. The amount of leaf litter was greater in unmown plots offering more food and shelters than mown plots.

Snails clearly prefer the unmown conditions, both number of individuals and number of species were significantly higher there. The fact that the standardized RDA was not significant is probably caused by the fact that the same species dominated both assemblages, which masked the effect on non-abundant species. Indeed, when the effect of dominants was diminished by log-transformation of abundances in RDA (results not shown), the differences became significant $(\mathrm{F}=2.8, \mathrm{P}=0.0278)$. An obvious evidence of the qualitative difference between mown and unmown plots is the distribution of Galba truncatula: This semiaquatic species lives on edges of permanent or temporary water bodies. It would be unexpected in homogenous mown plots that lack any especially wet places. The most important factors influencing the diversity and composition of malacofauna are chemistry and $\mathrm{pH}$ of substratum and moisture. In general, land snails prefer high $\mathrm{pH}$ and high content of calcium; additionally, most species prefer high moisture (e.g., Ložek 1956). According to Martin and Sommer (2004), a snail fauna is influenced by moisture much more than $\mathrm{pH}$ level in meadows. In grasslands, abundance and diversity of snails seem to be maximal in abandoned and extensively managed meadows; both abundance and biodiversity decline in both earlier or later successional stages (Cremene et al. 2005). Shortening of vegetation in meadows by mowing or grazing is known to reduce both biodiversity and total densities of molluscs, probably due to decreasing humidity (Ausden et al. 2005, Boschi and Baur 2007, Labaune and Magnin 2002). In general, our data are in agreement with these papers. Our plots differed in management type but not in $\mathrm{pH}$ values. The fact that small patches of unmown meadow supported biodiversity of moluscs shows also how important it is to leave these unmown patches for biodiversity conservation.

There were more ant species on mown (seven species) than in unmown (four species) plots, but the difference was not significant, probably because of the low number of experimental plots. Also, the species found in mown plots only were extremely rare (Appendix 1). Thus, dominant species were the main difference between both types of plots: M. scabrinodis dominated in mown and M. ruginodis in unmown plots, although both species were present on plots of both types. The nest density of M. scabrinodis rapidly decreased from the internal areas of mown plots to internal areas of unmown plots. Probably, M. scabrinodis would be absent or nearly absent from the larger unmown plots. Similarly, M. ruginodis is very rare in the rest of mown meadow (unpublished results).

Grassland management regimes have a substantial impact on the composition and structure of ant assemblages (Lenoir 2009, Lenoir and Lennartsson 2010, Russel 2010, Wynhoff et al. 2011). Ant communities are influenced by the structure of vegetation rather than by species composition (Elmes and Wardlaw 1982, Englisch et al. 2005, Gallé 1975, 1991, Gallé et al. 1998, Grill et al. 2008). In Central European grassland ants, differences in optimal temperature and humidity exist even in species occupying the same locality (Elmes et al. 1998, Elmes and Wardlaw 1983, Seifert 2007). Both factors highly depend on the insolation, which is affected by the height and structure of vegetation. According to Zschokke et al. (2003), there are significant changes of temperature over a distance of few centimeters along the edge of mown-unmown plots. Our measurement (Lepš 1999) in the experiment containing the same treatments at the same locality (ca $10 \mathrm{~m}$ from the reported experiment) also shows higher temperatures in mown plots with other differences in temperature daily regime, which leads to the soil desiccation in mown plots. Thus, $M$. ruginodis was favoured in slightly cooler and M. scabrino- 
dis in slightly warmer sites; this pattern is well known from the literature (Elmes and Wardlaw 1983).

In addition to the other environmental factors, the direct aggressive competition for territories and/or food resources is unique feature of ants. Interestingly, $2 \mathrm{~m}$ x $2 \mathrm{~m}$ fragments are enough to establish relatively differently structured myrmecofauna, even if the whole area of fragments is easily accessible for ants from the other biotope. Probably, it is facilitated by the low aggressivity of Myrmica. Nearly all Myrmica species are subdominant, non-aggressive species that do not defend territory nor food resources, ignore each other and are ignored by more aggressive ants (Elmes et al. 1998, Fiedler 2001, Seifert 2007). Thus, interspecific relationships between Myrmica are reduced to the indirect competition mainly. Even in case of territorial and aggressive Lasius paralienus small scale fragmentation leads to differences in the nest density and distribution in $L$. paralienus only, not to differences in the species composition (Braschler and Baur 2003).

There was no difference in species composition between spider assemblages in mown and unmown plots. Spider community composition is affected by both physical structure and species composition of vegetation (e.g., Malumbres-Olarte et al. 2012). In Central Europe, mowing usually reduces biodiversity of spiders (Cizek et al. 2012), especially those species linked to litter (Cattin et al. 2003). Our results does not support these observations, but the significantly higher number of individuals in mown plots can be explained by the vegetation structure and possible bias of the sampling method: tall vegetation with a thick layer of litter in unmown plots offers more space for movement of spiders. Thus, the probability that an individual will be captured in the pitfall trap is lower in unmown plots than in the mown ones.

In our experimental locality, in which, with the exception of experimental plots mown, the unmown plots can be considered as "islands" in mown "sea". From this point of view, the rate of differentiation of communities in mown and unmown plots might be related to the dispersal ability of the organisms under consideration.

Passive dispersal is usually possible for a distance of many kilometers in all selected groups but such dispersal offers no or little chance for an individual to actively select the target site (all seed dispersal of plants; passive transport of snails). In part, this is also true for ballooning of spiders and probably for aerial dispersal of ant queens. The ability to change and select habitats during their life time seems to play more important role in forming communities in our small experimental plots.

Plants commonly use passive seed dispersal mechanisms such as wind, water, and animal dispersal (e.g., Fenner 2000). However, targeted placement of offspring by vegetative spreading has been demonstrated in our experimental locality (Macek and Lepš 2003), in this case, dispersal distances not exceeding several centimeters. We have also observed that some species in this locality are able to spread vegetatively to longer distances (up to $1 \mathrm{~m}$ per year) by underground stolons (e.g., Lysimachia vulgaris, Carex hartmannii).
The rate of active dispersal of land snails is up to $0.1 \mathrm{~km}$ per year in case of large species, but smaller species disperse at a much slower rate. The majority of land snail species do not disperse more than 2-3 m per month and in the case of small species the dispersal rate does not exceed several tens of centimeters per year (Grimm and Paill 2001, KuźnikKovalska and Roksela 2009, Popov and Kramarenko 2004). Some species are reported to be dispersed passively, above all by humans (Aubry et al. 2006, Baker 1988) and birds (Gittenberger et al. 2006, Kawakami et al. 2008, Rees, 1965).

Queens of the majority of ant species are able to disperse for a distance of many kilometers (Gomez and Abril 2012, Goodisman et al. 2000). Little is known about the selection of nesting sites by winged queens. Usually, queens fly to the mating place, break off their wings shortly after mating and continue to find the right place by walking (Hölldobler and Wilson 1990). However, many queens that are captured in pitfall traps usually belong to species that do not live in that habitat (pers. observation; J. Frouz, pers. communication). This indicates that active site selection via flying is rather poor. During the lifetime of a colony, ants are able to move a whole nest, in the case of Myrmica ants, the dominant taxon on our plots, usually up to 2 meters (Elmes et al. 1998).

Spiders have the best individual active dispersal abilities within all studied taxa. Aerial dispersal of juveniles to a distance of many kilometers is common in the majority of species and both juveniles and adults can balloon in some taxa (e.g., Linyphiidae) (Duffey 1998). This dispersal is not active but individuals can balloon repeatedly until they find an optimal site. Moreover, adult spiders can further disperse by walking.

The grain of the mosaic was more than one order larger than the within-season active dispersal ability of most plants (i.e., vegetative dispersal is the main dispersal mechanism in the locality), and the differences were highly significant, whereas the vagility of spiders exceed the grain of the mosaic considerably, and only quantitative difference was found. The active dispersal abilities of snails and ants colonies lay between these groups as well as the differences between their communities. But - beside the active dispersal abilities - other factors (e.g., nutrition requirements or the ecophysiology) must play an important role. Mowing directly affects mainly plants, and so it changes their competitive equilibria (Lepš 1999). Although in our case the abandonment of mowing causes a decrease in species richness of plants (and so it does not contribute to species coexistence in the mosaic), some plants still prefer the unmown plots (Lepš 2014). For example, Lysimachia vulgaris usually does not flower in mown plots, and is much weaker there. It is then possible that its existence in mown plots is due to seed input and/or penetrating stolons from the unmown plot, and the mosaic contributes to its persistence there. Naturally, some endangered species can also prefer unmown meadows (Valkó et al. 2012). Mowing also affects abiotic characteristics such as temperature and humidity. These factors are important for animals, either directly (e.g., via regulation of their development) or indirectly (e.g., via changing the availability of food). Differences in biodiversity may be more obvious in larger plots as it is 
known from literature cited above. It seems that leaving of small $2 \times 2 \mathrm{~m}$ fragments of unmown plots in mown meadow might enhance the biodiversity in at least some groups of organisms. The results also show that various groups of organisms are affected differently by the same type of management; the same management (e.g., mowing, but it is true also for other management measures) that enhances biodiversity in one group might be detrimental for another group. Consequently, there is no ideal management suiting all types of organisms, and diversity and mosaic structure of landscape are probably important to maintain the biodiversity of various organisms. Our results show that also the small scale mosaic helps to maintain diversity in some groups of organisms.

Acknowledgements. We are obliged to M. Šorf, J. Robovský and P. Robovská for help with the pitfall traps. We are grateful to N. Plowman for her corrections of our English, and editor and two anonymour reviewers for their helpful comments. The research was supported by the Czech Ministry of Education "Specifický výzkum 2120, 2011" program and GAČR 13-17118S.

\section{References}

Aubry, S., C. Labaune, F. Magnin, P. Roche and L. Kiss. 2006. Active and passive dispersal of an invading land snail in Mediterranean France. J. Anim. Ecol. 75: 802-813.

Ausden, M., M. Hall, P. Pearson and T. Strudwick. 2005. The effects of cattle grazing on tall herb fen vegetation and molluscs. Biol. Cons. 122: 317-326

Baker, G.H. 1988. Dispersal of Theba pisana (Mollusca: Helicidae). J. Appl. Ecol. 25: 889-900.

Báldi, A., P. Batáry and D. Klejn. 2013. Effects of grazing and biogeographic regions on grassland biodiversity in Hungary - analysing assemblages of 1200 species. Agr. Ecosyst. Environ. 2013: 28-34.

Balmer, O. and A. Erhardt. 2000. Increased butterfly diversity after 10 -year succession on extensively grazed calcareous grasslands in the Jura mountains of north-west Switzerland. Mitt. Dtsch. Ges. Allg. Agnew. Ent. 12: 259-262.

Boschi, C. and B. Baur. 2007. Effects of management intensity on land snails in Swiss nutrient-poor pastures. Agr. Ecosyst. Environ. 120: 243-249.

Brandao, C.R.F., R.R. Silva and R.M. Feitosa. 2011. Cerrado grounddwelling ants (Hymenoptera: Formicidae) as indicators of edge effects. Zoologia 28: 379-387.

Braschler B. and B. Baur. 2003. Effects of experimental small-scale grassland fragmentation on spatial distribution, density and persistence of ant nests. Ecol. Entomol. 28: 651-658.

Cattin, M.-F., G. Blandenier, C. Banašek-Richter and L.-F. Bersier. 2003. The impact of mowing as a management strategy for wet meadows on spiders (Araneae) communities. Biol. Conserv. 113: 179-188.

Cizek, O., J. Zamecnik, R. Tropek, P. Kocarek and M. Konvicka. 2012. Diversification of mowing regime increases arthropods diversity in species-poor cultural hay meadows. J. Ins. Conserv. 16: $215-226$.

Cremene, C., G. Groza, L. Rakosy, A.A. Schileyko, A. Baur, A. Erhard and B. Baur. 2005. Alterations of steppe-like grasslands in Eastern Europe: a threat to regional biodiversity hotspots. Conserv. Biol. 19: 1606-1618.

De Koninck, W., H. De Koninck, J.Y. Baugnee and J. P. Maelfait. 2007. Ant biodiversity conservation in Belgian calcareous grasslands: active management is vital. Belgian J. Zool. 137: 137-146.

Diamond, S.E., D.M. Sorger, J. Hulcr, S.L. Pelini, I. Del Toro, C. Hirsch, E. Oberg and R.R. Dunn. 2012. Who likes it hot? A global analysis of the climatic, ecological, and evolutionary determinants of warming tolerance in ants. Global Change Biol. 18: 448-456.

Doležal, J., Z. Mašková, J. Lepš, D. Steinbachová, F. de Bello, J. Klimešová, O. Tackenberg, F. Zemek and J. Květ. 2011. Positive long-term effect of mulching on species and functional trait diversity in a nutrient-poor mountain meadow in Central Europe. Agr. Ecosyst. Environ 145: 10-28.

Dover, J.W., A. Rescia, S. Fungarino, J. Fairburn, P. Carey, P. Lunt, R.L.H. Dennis and C.J. Dover. 2010. Can hay harvesting detrimentally affect adult butterfly abundance? J. Ins. Conserv. 14: 413-418.

Duffey, E., 1998. Aerial dispersion in spiders. Proccedings of the 17th European Colloquium, Edinburgh, 1997. pp. 187-191.

Ellison, A.M. 2012. Out of Oz: opportunities and challenges for using ants (Hymenoptera: Formicidae) as biological indicators in north-temperate cold biomes. Myrmecol. News 17: 105-119.

Elmes, G.W. and J.C. Wardlaw. 1982. A population study of the ants Myrmica sabuleti and Myrmica scabrinodis living at two sites in the South of England. II. Effect of above-nest vegetation. $J$. Anim. Ecol. 51: 665-680.

Elmes, G.W. and J.C. Wardlaw. 1983. A comparison of the effect of temperature on the development of large hibernated larvae of four species of Myrmica (Hym. Formicidae). Insectes Soc. 30: 106-118.

Elmes, G.W., J.A. Thomas, J.C. Wardlaw, M. Hochberg, R.T. Clarke and D.J. Simcox. 1998. The ecology of Myrmica ants in relation to the conservation of Maculinea butterflies. J. Ins. Conserv. 2: 67-78.

Englisch, T., F.M. Steiner and B.C. Schlick-Steiner. 2005. Fine-scale grassland assemblage in Central Europe: ants tell another story than plants (Hymenoptera: Formicidae; Spermatophyta). Myrm. Nachr: 7: 61-67.

Fenner, M., 2000. Seeds. The Ecology of Regeneration in Plant Communities. 2nd ed. CABI, Wallingford.

Fenner, M. and A. Palmer. 1998. Grassland management to promote diversity: creation of a patchy sward by mowing and fertiliser regimes. Field Stud. 9: 313-324.

Fiedler, K. 2001. Ants that associate with Lycaenidae butterfly larvae: diversity, ecology and biogeography. Diversity and Distributions 7: 45-60.

Gallé, L. 1975. Factors stabilizing the ant populations (Hymenoptera: Formicidae) in the grass association in the Tisca basin. Tiscia 10: $61-66$

Gallé, L. 1991. Structure and succession of ant assemblages in a north European sand dune area. Holarctic Ecol. 14: 31-37.

Gallé, L., L. Körmöczi and J. Kerekes. 1998. Structure of ant assemblages in a Middle-European successional sand-dune area. Tiscia 31: 19-28.

Gathmann A., H.J. Greiler and T. Tscharntke. 1994. Trap-nesting bees and wasp colonizing set-aside fields - succession and bodysize, management by cutting and sowing. Oecologia 98: 8-14.

Gerard, M., M. El Kahloun, J. Rymen, O. Beauchard and P. Meire. 2008. Importance of mowing and flood frequency in promoting 
species richness in restored floodplains. J. Appl. Ecol. 45: 17801789.

Gittenberger, E., D.S.J. Groenenberg, B. Kokshoom and R.C. Preece. 2006. Molecular traits from hitch-hiking snails. Nature 439: 409.

Gomez, C. and S. Abril. 2012. Nuptial flights of the seed-harvester ant Messor barbarus (Linnaeus, 1767) (Hymenoptera: Formicidae) in the Iberian Peninsula: synchrony, spatial scale and weather conditions. Myrmecol. News 16: 25-29.

Goodisman, M.A.D., DeHeer, C.J. and K.G. Ross. 2000. Unusua behavior of polygyne fire ant queens on nuptial flights. J. Ins. Behav. 13: 455-468.

Grandchamp, A.C., A. Bergamini, S. Stofer, J. Niemela, P. Duelli and C. Scheidegger. 2005. The influence of grassland management on ground beetles (Carabidae, Coleoptera) in Swiss montane meadows. Agr. Ecosyst. Environ. 110: 307-317.

Grill, A., D.F.R. Cleary, C. Stettmer, M. Bräu and J. Settele. 2008, A mowing experiment to evaluate the influence of management on the activity of host ants of Maculinea butterflies. J. Ins. Conserv. 12: 617-627.

Grimm, B. and W. Paill. 2001. Spatial distribution and home-range of the pest slug Arion lusitanicus (Mollusca: Pulmonata). Acta Oecol. 22: 219-227.

Hölldobler, B. and E.O. Wilson. 1990. The Ants. Springer, Berlin.

Horsák, M., L. Juřičková, J. Picka. 2013. Měkkýši České a Slovenské republiky. Molluscs of the Czech and Slovak Republics. Kabourek, Zlín.

Humbert, J.Y., J. Ghazoul and T. Walter. 2009. Meadow harvesting techniques and their impacts on field fauna. Agr. Ecosyst. Environ. 130: 1-8.

Humbert, J.Y., J. Ghazoul, G.J. Sauter and T. Walter. 2010. Impact of different meadow mowing techniques on field invertebrates. $J$. Appl. Entomol. 134: 592-599.

Humbert, J.-Y., J. Pellet, P. Buri and R. Arlettaz. 2012. Does delaying the first mowing date benefit biodivesity in meadow? Environmental Evidence 1: 9.

Hurlbert, S.H., 1971. The nonconcept of species diversity: a critique and alternative parameters. Ecology 52: 577-586.

Huusela-Veistola, E. and A. Vasarainen. 2000. Plant succession in perennial grass strips and effects on the diversity of leafhoppers (Homoptera, Auchenorrhyncha). Agr. Ecosyst. Environ. 80: 101112.

Hyvonen, T. and E. Huusela-Veistola. 2011. Impact of seed mixture and mowing on food abundance for farmland birds in set-asides. Agr. Ecosyst. Environ. 143: 20-27.

Kawakami, K., Wada, S. and S. Chiba. 2008. Possible dispersal of land snails by birds. Ornithol. Sci. 7: 167-171.

Konvicka, M., J. Benes, O. Cizek, F. Kopecek, O. Konvicka and L. Vitaz. 2008. How too much care kills species: Grassland reserves, agri-environmental schemes and extinction of Colias myrmidone (Lepidoptera: Pieridae) from its former stronghold. J. Ins. Conserv. 12: 519-525.

Kubát, K., L. Hrouda, J. Chrtek, Z. Kaplan, J. Kirschner and J. Štěpánek (eds), 2002. Klíč ke květeně České republiky. Academia, Praha.

Kučera, J., J. Váňa and Z. Hradílek. 2012. Bryophyte flora of the Czech Republic: updated checklist and Red List and a brief analysis. Preslia 84: 813-850.

Kuussaari, M., T. Hyvonen and O. Harma. 2011. Pollinator insects benefit from rotational fallows. Agr. Ecosyst. Environ. 143: 2836.
Kuźnik-Kovalska, E. and A. Roksela. 2009. Life cycle of Perforatella bidentata (Gmelin, 1791) (Gastropoda: Pulmonata: Helicidae). Folia Malacol. 17: 199-214.

Labaune, C. and F. Magnin. 2002. Pastoral management vs. abandonment in Mediterranean uplands: impact on land snail communities. Global Ecol. Biogeogr. 11: 237-245.

Lenoir, L. 2009. Ant species composition and richness in different types of semi-natural grasslands. Russ. J. Ecol. 40: 471-476.

Lenoir, L. and T. Lenartsson. 2010. Effect of timing of grazing on arthropod communities in semi-natural grasslands. J. Insect Sci. 10:60

Lepš, J. 1999. Nutrient status disturbance and competition: an experimental test of relationships in a wet meadow. J. Veg. Sci. 10: $219-230$

Lepš, J. 2004. Variability in population and community biomass in a grassland community affected by environmental productivity and diversity. Oikos 107: 64-71.

Lepš, J. 2014. Scale-and time-dependent effects of fertilization, mowing and dominant removal on a grassland community during a 15-year experiment. J. Appl. Ecol. 51: 978-987.

Ložek, V. 1956. Klič československých měkkýšů. Vydav. Slov. akad. vied SAV, Bratislava.

Macek, P. and J. Lepš. 2003. The effect of environmental heterogeneity on clonal behaviour of Prunella vulgaris L. Plant Ecol. 168: 31-43.

Malumbres-Olarte J., C.J. Vink, J.G. Ross, R.H. Cruickhank and M Paterson. 2012. The role of habitat complexity on spider communities in native alpine grasslands of New Zealand. Insect Conserv. Diver. 6: 124-134.

Marini, L., P. Fontana, A. Battisti and K. J. Gaston. 2009. Agricultural management, vegetation traits and landscape drive orthopteran and butterfly diversity in a grassland-forest mosaic: a multi-scale approach. Insect Conserv. Diver. 2: 213-220.

Martin, K. and M. Sommer. 2004. Effect of soil properties and land management on the structure of grassland snail assemblages in SW Germany. Pedobiologia 48: 193-203.

Noordijk, J., A. P. Schaffers, T. Heijerman, P. Boer, M. Gleichman and K. V. Sykora. 2010. Effects of vegetation management by mowing on ground-dwelling arthropods. Ecol. Eng. 36: 740-750.

Peck, S.L., B. McQuaid and C.L. Campbell. 1998. Using ant species (Hymenoptera: Formicidae) as a biological indicator of agroecosystem condition. Environ. Entomol. 27: 1102-1110.

Platnick, N.I. 2013. The world spider catalog, version 14.0. American Museum of Natural History, online at http://research.amnh.org/ entomology/spiders/catalog/index.html DOI: 10.5531/db.iz. 0001 .

Popov, V.N. and S. Kramarenko. 2004. Dispersal of land snails of the genus Xeropicta Monterosato, 1892 (Gastropoda; Pulmonata; Hygromiidae). Russ. J. Ecol. 35: 263-266.

Rees, W.J., 1965. The aerial dispersal of Mollusca. Proc. Malacol. Soc. Lond. 36: 269-282.

Russel, F. 2010. The short-term impacts of burning and mowing on prairie ant communities of the Oak Openings Region. MSc. Thesis. http://etd.ohiolink.edu/view.cgi/Friedrich $\% 20$ Russell\%20L.pdf?toledo1271382165 retrieved on 20 May 2012.

Scanga, S.E. and D.J. Leopold. 2012. Managing wetland plant populations: Lessons learned in Europe may apply to North American fens. Biol. Conserv. 148: 69-78.

Scohier A. and B. Dumont. 2012. How do sheep affect plant communities and arthropod populations in temperate grasslands? Animal 6: 1129-1138. 
Schwab, A., Dubois, D., Fried, P.M., Edwards, P.J., 2002. Estimating the biodiversity of hay meadow in north-eastern Schwitzerland on the basis of vegetation structure. Agriculture, Ecosystems and Environment 93: 197-209.

Seifert, B. 2007. Die Ameisen Mittel- und Nordeuropas. Lutra Verlags- und Vertriebsgesellschaft, Tauer.

Šmilauer, P. and J. Lepš. 2014. Multivariate analysis of ecological data using CANOCO 5. 2nd edition, Cambridge University Press, Cambridge.

Steffan-Dewenter, I. and K. Leschke. 2003. Effects of habitat management on vegetation and above-ground nesting bees and wasps of orchard meadows in Central Europe. Biodivers. Conserv. 12: 1953-1968.

ter Braak, C.J.F. and P. Šmilauer. 2012. Canoco Reference Manual and User's Guide: Software for Ordination (version 5.0). Microcomputer Power, Ithaca, NY, USA.

Valkó, O., P. Török, G. Matus and B. Tóthmérész. 2012. Is regular mowing the most appropriate and cost-effective management maintaining diversity and biomass of target forbs in mountain hay meadows? Flora 207: 309.

Vítová, A. and J. Lepš. 2011. Experimental assessment of dispersal and habitat limitation in a oligotrophic meadow. Plant Ecol. 212: 1231-1242.

Weiner, C.N., M. Werner, K.E. Linsenmair and N. Bluthgen. 2011. Land use intensity in grasslands: Changes in biodiversity, species composition and specialisation in flower visitor networks. Basic Appl. Ecol. 12: 292-299.
Wynhoff, I., R. van Gestel, C. van Swaay and F. van Langevelde. 2011. Not only the butterflies: Managing ants on road verges to benefit Phengaris (Maculinea) butterflies. J. Insect Conserv. 15: 189-206.

Zechmeister, H.G., I. Schmitzberger, B. Steurer, J. Peterseil and T. Wrbka. 2003. The influence of land-use practices and economics on plant species richness in meadows. Biol. Conserv. 114: 165-177.

Zschokke, S., C. Dolt, H.-P. Rusterholz, P. Oggier, B. Braschler, G.H. Thommen, E. Lüdin, A. Erhardt and B. Baur. 2003: Short-term responses of plants and invertebrates to experimental small-scale grassland fragmentation. Oecologia 125: 559-572.

Received June 28, 2014 Revised December 8, 2014

Accepted January 3, 2015

\section{Appendices}

Appendix 1. Average cover of plants and abundances of molluscs, ant nests and spiders.

Appendix 2. Results of rarefaction of pooled samples from all the mown/unmown plots - of the relationships between number of individuals/nests and number of species: molluscs, ants and spiders.

The file may be downloaded from www.akademiai.com. 